\title{
Firm local embeddedness in an insular region: The Åland Islands compared to Finland
}

(In memoriam, Jouko Kinnunen)

\author{
Edvard Johansson \\ Faculty of Social Sciences, Business and Economics, Åbo Akademi University, Finland \\ edvard.johansson@abo.fi (corresponding author)
}

\section{Jouko Kinnunen}

Juhana Peltonen

Faculty of Social Sciences, Business and Economics, Åbo Akademi University, Finland juhana.peltonen@abo.fi

\begin{abstract}
The present study analyzes the difference between the Åland Islands - an insular and peripheral part of Finland - and Finland as a whole in terms of firm local embeddedness. The analysis utilizes matched employee-employer longitudinal data for all businesses in Finland, including the Åland Islands, from 2006 to 2014. Local embeddedness is modelled both as tenure (the number of years a key stakeholder in a firm has lived in the same municipality as the firm) and by calculating the geographical distance the key stakeholder lives from the focal firm. Contrary to our expectations, we find that for our tenure measure of local embeddedness, firms are actually less locally embedded in the peripheral region than in the larger country. However, our distance measure of local embeddedness performs as expected with firms in the peripheral region. We hypothesize that that there may be an optimal level of local embeddedness, above which a local firm does not necessarily gain by further increasing its local embeddedness.
\end{abstract}

Keywords: island economy, Finland, local embeddedness, peripherality, small firms, Åland Islands

https://doi.org/10.24043/isj.171 • Received February 2021, Early access August 2021

(C) Island Studies Journal, 2022

\section{Introduction}

Does being located in a peripheral region increase or decrease firm local embeddedness? On the one hand, geographic distance and different legal rules may make it more difficult for firms in a peripheral region to form networks with key stakeholders and customers further afield, thereby increasing local embeddedness. On the other hand, it is possible that firms in the peripheral region are well aware that there is a limit to how much local embeddedness is 
good for their performance, and will therefore make extra effort to network with stakeholders that are not local, which would tend to decrease local embeddedness. This is important, because recent research has shown that more locally embedded firms have better firm performance (e.g., Baù et al., 2019; Dahl \& Sorenson, 2012).

The origins of embeddedness can be traced back to Polanyi (1944), and the concept of local embeddedness was later popularized by Mark Granovetter (e.g., Granovetter, 1985, 2005). Individuals and firms are, in this sense, shaped by their location, and are to different extents involved and embedded in their location. Local embeddedness describes the connections to the location and the networks with other economic actors within the same location. The degree of local embeddedness for an individual varies given factors such as personal history, work experience, and extent of personal and professional networks. For firms, local embeddedness is related to employee composition, structure of ownership, which suppliers the firm uses, where its customers are located, and professional networks. The concept of local embeddedness has also been applied in the context of entrepreneurship and can, in this context, be described as the involvement of economic actors in a geographically bound social structure (Granovetter, 1973; Hess, 2004). Studies confirm the importance of being locally embedded for firm performance (Baù et al., 2019) and, within entrepreneurship research, it has been argued that local embeddedness influences the behavior of firms in important ways (e.g., Bird \& Wennberg, 2014).

Within the research that has, from an embeddedness point of view, specifically focused on the distinction between firms located in peripheral areas and those that are not, one strand of research has developed various models of types of firms located in peripheral areas and how they vary in terms of local embeddedness (e.g., Korsgaard et al., 2015; Müller \& Korsgaard, 2018). There are also studies that have investigated how the local embeddedness of peripheral firms affects business performance (e.g., Dubois, 2016). In particular, Greenberg et al. (2018) investigated and discussed strategies that firms located in peripheral regions can employ in order to overcome the apparent challenges they face owing to their location, a consideration which is important also for the present study.

Despite this body of research, few (if any) studies investigate whether local embeddedness is different in a peripheral region compared to other regions by using representative and economy-wide quantitative data. Employing this type of data would give a more comprehensive view that is easier to generalize when compared to previous studies that have mostly been case-based or based on small samples of firms.

In this study, we focus on firms on the Åland Islands compared to firms in the rest of Finland, as an example of a peripheral region (the Åland Islands) and an export-oriented, open economy which is also a member of the European Union (Finland). The interest in the Alland Islands is not only due to its peripheral and insular location, but also due to the Åland Islands belonging to Finland and having relatively wide-reaching autonomy (Herolf et al., 2015). As such, while the basic legal structure of the Åland Islands is that of Finland as a whole, there are also deviations from within the boundaries of its local autonomy. In particular, some of the legal characteristics that differentiate the Åland Islands from the rest of Finland are likely to affect the local economy differently compared to the rest of Finland.

First, there are restrictions for non-residents regarding the possibilities to buy real estate on Åland. Contrary to standard EU rules, real estate not situated in zoned areas can only be purchased by individuals that possess the Åland Islands Right of Domicile, which is only 
granted to individuals who are Finnish citizens, have an adequate knowledge of the Swedish language, and have lived in the Åland Islands for at least five years.

Second, corporations that are registered on the Åland Islands must have an executive board majority of individuals that have the Aland Islands Right of Domicile, and only firms that are registered on the Åland Islands are allowed to operate on the Åland Islands. While there are some loopholes in these rules, they certainly make it more difficult for firms to establish themselves on the Åland Islands, likely contributing to a lack of competition and, as a result, possibly higher prices (Aalto-Setälä et al., 2004). Although the origins of these legal particularities are highly interesting in their own right, they are not the topic of the present paper; the interested reader is referred to Williams's (2007) Excluding to protect: Land rights and minority protection in international law for an exposition of the historic roots of the Åland Islands legal status.

A further characteristic of interest is the Åland Islands being a group of islands that are only accessible by air or by sea. The closest major cities or towns are Stockholm in Sweden, which is accessible in 30 minutes by plane or in about 5.5 hours by ferry, and Turku on the Finnish mainland, which is accessible by air or ferry in roughly the same amount of time as the Stockholm routes.

All in all, there are good reasons to consider the Åland Islands as a region that is peripheral, both in in its being surrounded by water as well as in the sense that is has some legal restrictions on how firms may localize. From a theoretical economics perspective, these issues can be seen as barriers to entry, which can be hypothesized to have a curbing effect on the in-migration of people and perhaps also on inward investment. Additionally, these barriers may also restrict out-migration of individuals, as well as dampen outward investment. An analogous theoretical case from labor economics would be that of employment protection legislation, which decreases both job creation and job destruction (Bassanini et al., 2014). Interestingly, one of the few quantitative empirical studies regarding business dynamics which includes the Åland Islands (Böckerman \& Maliranta, 2001) reports that, according to almost every indicator examined in their study (job creation, job destruction, job reallocation, hiring rate, separation rate, etc.), the Åland Islands had the lowest rate of structural change of all Finnish regions.

In this paper, we hypothesize that the legal and geographical barriers to entry that exist in the Åland Islands will increase local embeddedness. The main channel for this is that the barriers to entry regarding migration, board membership rules, and purchases of real estate for firms discussed above will induce individuals to live longer in the same place, as well as decrease both market entry and exit of firms. This, in turn, means that we would expect to see more local embeddedness in a place that is more "secluded" from the rest of the world than nearby regions. Therefore, to some extent, we pursue the issue of a "dark" side of local embeddedness, whereby firms can suffer from too much local embeddedness (Uzzi, 1999). Our reasoning is that the optimal level of local embeddedness that a firm would seek to attain, under no legal or geographical restrictions, would be lower than what firms have in more insular region such as the Åland Islands.

Empirically, the analysis in this paper is performed using firm-level data for all Finnish firms (including those from the Åland Islands) from 2006 to 2014. With this data, we estimate models with various operationalizations of local embeddedness as our dependent variable. We operationalize local embeddedness for various firm stakeholders through their place tenure and average straight-line distance from the firm over time. The stakeholders we examine include the firms' CEOs, owners, board chairpersons, managers, board members, and employees. We 
compute firm-level averages for each of these stakeholder types from person-level data. Our independent variables are factors that can explain why some firms are more locally embedded than others. One of our independent variables is a dummy indicating whether the firm in question is located on the Åland Islands.

Interestingly, we do not find unequivocal evidence of local embeddedness being at a higher level in the peripheral region compared to the less peripheral, as analysis of one of our two measures of local embeddedness instead shows the opposite result. Thus, barriers to entry may be one contributing factor to local embeddedness, but other types of firm behavior may counteract the effects of being located in a peripheral region.

The results of this paper have implications for the success and strategies for peripheral firms, as it provides insights into the obstacles that they must overcome in order to compete in broader markets. Furthermore, the Åland Islands is in itself an interesting example of a peripheral region. First, it is primarily one island (or, rather, an archipelago of islands), which adds an extra complication in terms of travelling and transportation to and from the region. Second, it is an autonomous region within Finland, and can thus be compared to many autonomous regions in Europe and elsewhere - such as the Faroe Islands, the Canary Islands, or South Tyrol - in having somewhat different legal rules compared to their respective 'home' countries.

\title{
Some characteristics of the Aland Islands economy
}

The Åland Islands are situated between Finland and Sweden in the Baltic Sea, and have some 30,000 inhabitants, compared to around 5.5 million in Finland as a whole. The Åland Islands is a wealthy and economically successful region in the European Union (EU). GDP per capita is $26 \%$ above the EU average and the employment rate for 20-64 year-olds is a staggering $88 \%$ (Eurostat, n.d.). The reasons for this are likely manifold, but the success of the Åland shipping industry and the legal opportunity to sell tax-free alcohol, tobacco, and cosmetics on board ferries operating between Finland and Sweden is likely one explanation (Kinnunen, 2005). The ability to sell tax-free goods on these passenger ferries is a consequence of the Åland Island's legal status in the EU (Tax Administration, n.d.). A special protocol in regard to Finland's relations with the EU stipulates that:

\begin{abstract}
Åland shall be regarded as a third territory with respect to indirect taxation, which enables the sale of tax free goods to passengers travelling between the Åland Islands and other EU Member States, even though the tax exemption in the traffic between EU Member States ended as of 1 July 1999. (Ministry for Foreign Affairs of Finland, n.d., para. 26)
\end{abstract}

In addition to enabling tax-free sales on passenger ferries between Sweden and Finland, this exception also applies for passengers travelling between the Åland Islands and mainland Finland (Ministry for Foreign Affairs of Finland, n.d.). This economic success makes any investigation into the workings of the Åland economy all the more interesting.

\section{Data}

We utilized panel data consisting of all firms in Finland during the period 2006-2014. The data were aggregated from several sources. First, we obtained information on firms' and their establishments' locations at the municipality level from Statistics Finland's Enterprise Statistics; 
these data were then linked to accounting measures from the Financial Statement data panel. Next, Finnish Longitudinal Employer-Employee Data (FLEED) (Maliranta et al., 2009; Statistics Finland, n.d.) was used to obtain employee-firm and employee-establishment links, along with an abundance of person-level demographic data (including occupation) for all persons between the ages of 15 to 70 residing in Finland. We obtained ultimate (anonymized) details of top person-owners of limited liability companies from the Finnish Longitudinal OWNer-Employer-Employee (FLOWN) database (Maliranta \& Nurmi, 2019), and obtained data on CEOs, chairpersons, and board members from the Finnish Patent and Registry office. Limited liability companies are required by law to register changes in these roles without delay, thus assuring the accuracy of the data obtained. All of the aforementioned datasets were then linked using encrypted identifiers. Given that the data comes from registers, they are free from errors that may occur in surveys and are, therefore, highly reliable. The data also include information on the geographical location of the firms.

The operationalization of local embeddedness was based on location panel data of individuals' places of residence (Finnish Longitudinal Employer-Employee Data; FLEED) and the locations of firms' plants/establishments at municipality-level. Our operationalization procedure started from the distances in person-role-firm dyads; the same person can be related multiple times to the same or different firm(s) by having different stakeholder roles. We then proceeded to the firm-level by taking the mean of these person-role-firm distances. We measured local embeddedness for six firm stakeholder types: CEO, owner, manager (other than CEO), employees, chairperson, and board members.

FLEED enabled us to associate employees with plants/establishments in firms (at time $\mathrm{T}$ ), which consequently enabled us to operationalize the degree to which a person's current and past places of residence $(\mathrm{T}-18 \ldots \mathrm{T})$ are in the proximity of the current location of the plant/establishment (at T) where they work (at T). In the case of owners, CEOs, chairpersons, and other board members, we needed to address the question of where the firm is located, in case it has multiple establishments. To solve that issue, we assumed the location to be the largest plant/establishment of the firm, as measured by its number of employees. Given these location data and person-firm associations, we then needed to define what proximity means to compute local embeddedness. As our baseline approach, we considered a location match to occur only if the municipality of residence matched the location of the firm's plant/establishment. Municipalities are the smallest administrative unit in Finland, of which there are 311. Thus, we operationalized embeddedness through the number of years a person has resided in the same municipality as the plant/establishment. The number of years in the same location as the firm captures a person's place tenure. Firm-level place tenures for each stakeholder type were subsequently obtained by taking firm-level averages of the respective person-level place tenure values (cf., Baù et al., 2019).

We also computed more accurate geographic distances using coordinate data on the population centers of the municipalities (computed for the year 2014). This enabled us to capture local embeddedness in terms of the geographical distance between firm stakeholder types (the same six as used before) and the firm, rather than viewing distance simply as a dichotomous variable (i.e., same or different municipality). We computed the straight-line distance between a person's municipality of residence $(\mathrm{T}-18 \ldots \mathrm{T})$ and the firm/establishment (at T) and took the average of these values on the person level. Finally, by taking firm-level 
averages (again for all stakeholder types), we arrived at our distance-based embeddedness operationalization, to which we refer simply as distance measured in kilometers.

\section{The empirical model}

In order to investigate whether firms located in the Åland Islands are more locally embedded than those in Finland in general, we employed a simple regression model where our measures of local embeddedness described in the previous section appear as y-variables (in separate regressions). Among our x-variables, we included a dummy variable indicating that the firm is located on the Alland Islands. We also included a number of control variables: the age of the firm, the number of the employees in the firm, the total assets of the firm, the turnover of the firm, the number of establishment sites of the firm, whether the firm is a family firm, the area of the municipality where the firm is located, a set of industry indicator variables, and a set of annual dummies. In the regression, the standard errors were clustered at the firm level.

Some choices of our control variables are obvious, such that the degree of local embeddedness may correlate with the industry or with the age or the size of the firm, measured either as the number of employees, the turnover of the firm, or the total assets of the firm. In addition, our descriptive statistics (see Table 3) point out that firms in the Åland Islands are systematically different in these respects from firms in the Finnish mainland.

Whether the firm is a family firm or not has relevance for local embeddedness. In particular, prior research suggests that family firms are more locally embedded than non-family firms (Bird \& Wennberg, 2014). Further, given the differences in family firm prevalence between the Åland Islands and the Finnish mainland (see Table 3), we included a family firm dummy in the model.

We also included a control for the geographical size of the municipality in which the firm is located, measured in square kilometers. The idea behind this is that for a stakeholder (or any person, for that matter), moving between geographically small municipalities is not the same thing as moving between geographically large municipalities. Thus, if someone moves a fixed number of kilometers from his or her home, it is more likely that a municipal border is crossed if the municipality where a person originally lived is smaller in size. As both of our measures of embeddedness are at the municipal level, this is potentially important in the current study. Indeed, as our measure of place tenure is constructed as the number of years a key stakeholder has lived in the same municipality as where the firm is located, the introduction of the size of the municipality as a control variable may be of value. Thus, if a stakeholder moves across a municipal boundary, it will induce a change in both the tenure and the distance measure used. All other things being equal, a geographical move of a certain number of kilometers is more likely to be across a municipal boundary if the municipality is geographically smaller. Also, municipalities on the Åland Islands are geographically small, which could have a distorting effect on the results if not controlled for.

Finally, we included a variable that controlled for the number of establishment sites a firm has. The way our data is constructed, this may be important as both our place tenure measure and our distance measure of local embeddedness are measured to the firm's reported home municipality. This is clearly a choice that can be discussed, but the literature on how to measure local embeddedness empirically when a firm has two or several establishment sites has not yet been developed. 


\section{Results}

\section{Descriptive statistics}

We first provide some descriptive statistics on the Aland Islands business sector, based on the data used. Table 1 provides information regarding the total number of firms and the relative distribution of firms by industry in the Alland Islands and in the rest of Finland according to the NACE Rev. 2 statistical classification of economic activities in the EU (Eurostat, 2008). The data contains all firms in the period 2006-2014. The data is a panel, which means that most firms appear more than once. It was not possible to detail the table by year, as the number of firms in the Åland Islands is so small that rules regarding disclosure of statistical information prevent this information to be shown by year. Nevertheless, it is clear that the business sector in the Aland Islands diverges from that of the rest of Finland in terms of the number of firms in different industries. The relative share of all firms that operate in the agricultural sector is somewhat larger on the Åland Islands (3.1\%) than in the rest of Finland $(2.4 \%)$, although the share is low in both regions. The manufacturing industry has a larger share of the total number of firms in the rest of Finland (12.2\%) than on the Aland Islands (8.9\%). On the other hand, the accommodation and food service industry has a larger relative share of firms on the Aland Islands (8.7\%) than in the rest of Finland (4.6\%), highlighting that tourism is a more important industry on the Alland Islands than in the rest of Finland. Wholesale and retail trade also have a larger relative share of firms on the Åland Islands (26.2\%) than in the rest of Finland (19.7\%).

While the number of firms and the distribution of firms across industries is interesting, it does not tell us very much regarding the importance of the industry, as the average size of firms varies depending on industry.

Table 2 reports the average number of employees and average turnover per firm by industry in the Åland Islands and in the rest of Finland during 2006-2014. The table reveals some striking differences between firms in the Åland Islands and in the rest of Finland, with the foremost being the difference in the transportation and storage industry. The average firm size on the Aland Islands (90 employees) compared to the rest of Finland (9 employees) is very large; this is because, on the Åland Islands, the industry is dominated by a small number of shipowning firms. Another difference concerns the 'administrative support and service activities' industry, where the average firm size on the Aland Islands (5 employees) is considerably smaller than in the rest of Finland (15 employees). There are also large differences in the utilities industries, but they are perhaps not so surprising nor interesting.

All in all, it is evident that the business sector on the Åland Islands is quite different from that of the rest of Finland, based on the distribution of firms between industries and the average firm size within industries. This can be further demonstrated by studying the location quotient in the third column of Table 2 . The location quotient is calculated as the share of employment in the Åland Islands divided by the share of employment in the rest of Finland, by industry.

Table 3 presents the descriptive statistics of the variables used in our empirical model. In the table, the means, standard deviations, and medians of the variables presented for the Åland Islands and for the rest of Finland. The measures of local embeddedness vary quite a bit between the Åland Islands and the rest of Finland. Not surprisingly, the Distance measures are smaller for the Aland Islands than for the rest of Finland, which indicate that the key stakeholders of firms are living closer to the focal firms on the Åland Islands than in the rest 
of Finland. For instance, the average Distance for CEOs is $19.83 \mathrm{~km}$ on the Åland Islands compared to $25.92 \mathrm{~km}$ in the rest of Finland. Surprisingly however, this descriptive analysis show that our Place Tenure measures are in fact lower on the Alland Islands than in the rest of Finland, indicating that key stakeholders, according to this measure, are less locally embedded on the Alland Islands than in the rest of Finland. Again using the same stakeholder as an example, we can see that the Place Tenure measure for CEOs is 10.31 years for the Åland Islands compared to 12.36 years for the rest of Finland. In order to test whether these differences are also statistically significant, we performed a t-test for differences, which confirmed significance (see Table 3, column 1).

Table 1. Distribution of firms by industry in the Åland Islands and the rest of Finland 2006-2014.

\begin{tabular}{|c|c|c|c|c|}
\hline \multirow[b]{2}{*}{ Industry } & \multicolumn{2}{|l|}{ Åland } & \multicolumn{2}{|c|}{ Rest of Finland } \\
\hline & $\begin{array}{l}\text { Number of } \\
\text { firms }\end{array}$ & $\begin{array}{l}\text { Relative } \\
\text { share of total } \\
\text { firms }\end{array}$ & $\begin{array}{l}\text { Number of } \\
\text { firms }\end{array}$ & $\begin{array}{l}\text { Relative share } \\
\text { of total firms }\end{array}$ \\
\hline Agriculture, forestry, and fishing & 130 & 3.1 & 14,807 & 2.4 \\
\hline Mining and quarrying & 7 & 0.2 & 2126 & 0.3 \\
\hline Manufacturing & 367 & 8.9 & 76,101 & 12.2 \\
\hline $\begin{array}{l}\text { Electricity, gas, steam, and air } \\
\text { conditioning supply }\end{array}$ & 10 & 0.2 & 625 & 0.1 \\
\hline $\begin{array}{l}\text { Water supply; sewerage, waste } \\
\text { management, and remediation } \\
\text { activities }\end{array}$ & 19 & 0.5 & 2443 & 0.4 \\
\hline Construction & 624 & 15.1 & 10,6802 & 17.1 \\
\hline $\begin{array}{c}\text { Wholesale and retail trade; repair of } \\
\text { motor vehicles and motorcycles }\end{array}$ & 1084 & 26.2 & 123061 & 19.7 \\
\hline Transportation and storage & 256 & 6.2 & 46,648 & 7.5 \\
\hline $\begin{array}{l}\text { Accommodation and food service } \\
\text { activities }\end{array}$ & 360 & 8.7 & 28,830 & 4.6 \\
\hline Information and communication & 177 & 4.3 & 30,861 & 4.9 \\
\hline Financial and insurance activities & 56 & 1.4 & 7443 & 1.2 \\
\hline Real estate activities & 94 & 2.3 & 15,335 & 2.5 \\
\hline $\begin{array}{l}\text { Professional, scientific, and } \\
\text { technical activities }\end{array}$ & 489 & 11.8 & 89,510 & 14.3 \\
\hline $\begin{array}{l}\text { Administrative and support service } \\
\text { activities }\end{array}$ & 205 & 5.0 & 29,606 & 4.7 \\
\hline Education & 29 & 0.7 & 6559 & 1.1 \\
\hline $\begin{array}{l}\text { Human health and social work } \\
\text { activities }\end{array}$ & 108 & 2.6 & 26,058 & 4.2 \\
\hline Arts, entertainment, and recreation & 42 & 1.0 & 8244 & 1.3 \\
\hline Other service activities & 78 & 1.9 & 9015 & 1.4 \\
\hline
\end{tabular}


Table 2. Average number of employees and average turnover per firm by industry in Åland and the rest of Finland 2004-2016.

\begin{tabular}{|c|c|c|c|c|c|}
\hline \multirow[b]{2}{*}{ Industry } & \multicolumn{3}{|c|}{ Average umber of employees } & \multicolumn{2}{|c|}{ Average turnover $(€)$} \\
\hline & Åland & $\begin{array}{l}\text { Rest of } \\
\text { Finland }\end{array}$ & $\begin{array}{l}\text { Location } \\
\text { quotient }\end{array}$ & Åland & $\begin{array}{l}\text { Rest of } \\
\text { Finland }\end{array}$ \\
\hline $\begin{array}{l}\text { Agriculture, forestry, and } \\
\text { fishing }\end{array}$ & 5 & 5 & 0.92 & 846,004 & 556,542 \\
\hline Mining and quarrying & 7 & 9 & 0.27 & $1,205,157$ & $2,235,360$ \\
\hline Manufacturing & 12 & 17 & 0.36 & $1,854,471$ & $4,568,531$ \\
\hline $\begin{array}{l}\text { Electricity, gas, steam, and } \\
\text { air conditioning supply }\end{array}$ & 2 & 27 & 0.12 & $1,248,214$ & $25,981,307$ \\
\hline $\begin{array}{l}\text { Water supply; sewerage, } \\
\text { waste management, and } \\
\text { remediation activities }\end{array}$ & 17 & 10 & 1.38 & $2,690,161$ & $3,097,679$ \\
\hline Construction & 8 & 7 & 0.70 & $1,418,861$ & $1,225,937$ \\
\hline $\begin{array}{l}\text { Wholesale and retail trade; } \\
\text { repair of motor vehicles } \\
\text { and motorcycles }\end{array}$ & 8 & 8 & 0.92 & $3,007,314$ & $3,041,923$ \\
\hline Transportation and storage & 90 & 9 & 5.74 & $22,266,809$ & $1,370,660$ \\
\hline $\begin{array}{l}\text { Accommodation and food } \\
\text { service activities }\end{array}$ & 9 & 8 & 1.47 & 701,380 & 790,756 \\
\hline $\begin{array}{l}\text { Information and } \\
\text { communication }\end{array}$ & 11 & 8 & 0.82 & $1,681,794$ & $1,256,435$ \\
\hline $\begin{array}{l}\text { Financial and insurance } \\
\text { activities }\end{array}$ & 3 & 4 & 0.59 & 508,580 & $3,890,399$ \\
\hline Real estate activities & 2 & 4 & 0.32 & 345,665 & 746,721 \\
\hline $\begin{array}{l}\text { Professional, scientific, and } \\
\text { technical activities }\end{array}$ & 3 & 5 & 0.34 & 379,125 & 591,405 \\
\hline $\begin{array}{l}\text { Administrative and support } \\
\text { service activities }\end{array}$ & 5 & 15 & 0.24 & 545,268 & $1,048,642$ \\
\hline Education & 2 & 4 & 0.23 & 324,456 & 366,714 \\
\hline $\begin{array}{l}\text { Human health and social } \\
\text { work activities }\end{array}$ & 4 & 8 & 0.22 & 480,361 & 664,511 \\
\hline $\begin{array}{l}\text { Arts, entertainment, and } \\
\text { recreation }\end{array}$ & 7 & 5 & 0.75 & 970,553 & 639,758 \\
\hline Other service activities & 5 & 6 & 0.75 & 323,444 & 508,091 \\
\hline
\end{tabular}


Table 3. Descriptive statistics for variables in the empirical model.

\begin{tabular}{|c|c|c|c|c|c|c|}
\hline & Åland & & & Rest of & Inland & \\
\hline & Mean & St.dev & Median & Mean & St.dev & Median \\
\hline CEO Distance $(\mathrm{km})$ & $19.83 \star \star \star$ & 53.77 & 1.97 & 25.92 & 61.44 & 2.24 \\
\hline CEO place tenure (years) & $10.31 \star \star \star$ & 7.90 & 11.00 & 12.36 & 7.46 & 16.00 \\
\hline $\mathrm{N}$ & 2323 & & & 438947 & & \\
\hline Owner Distance $(\mathrm{km})$ & $18.52 \star \star \star$ & 48.75 & 3.65 & 29.65 & 61.92 & 6.57 \\
\hline Owner place tenure (years) & 10.54 & 6.83 & 11.00 & 11.95 & 6.79 & 13.50 \\
\hline $\mathrm{N}$ & 4090 & & & 619477 & & \\
\hline Manager Distance (km) & $24.32^{\star \star \star}$ & 51.91 & 4.57 & 30.31 & 58.13 & 9.22 \\
\hline Manager place tenure (years) & $9.03 \star \star \star$ & 7.33 & 9.00 & 11.12 & 7.32 & 12.00 \\
\hline $\mathrm{N}$ & 1255 & & & 179110 & & \\
\hline Employee Distance (km) & $27.70^{\star \star \star}$ & 48.89 & 10.73 & 34.48 & 56.74 & 15.40 \\
\hline Employee place tenure (years) & $7.78^{\star \star \star}$ & 5.94 & 6.61 & 10.02 & 6.07 & 9.80 \\
\hline $\mathrm{N}$ & 4038 & & & 610641 & & \\
\hline Chairman Distance $(\mathrm{km})$ & $20.06 \star \star \star$ & 55.92 & 1.04 & 33.22 & 77.04 & 2.69 \\
\hline Chairman place tenure (years) & $10.44 \star \star \star$ & 8.24 & 12.00 & 11.43 & 8.03 & 15.00 \\
\hline $\mathrm{N}$ & 2305 & & & 273744 & & \\
\hline Board member Distance $(\mathrm{km})$ & $16.40 \star \star \star$ & 41.44 & 3.52 & 28.84 & 64.03 & 4.45 \\
\hline $\begin{array}{l}\text { Board member place tenure } \\
\text { (years) }\end{array}$ & $10.50 \star \star \star$ & 7.17 & 11.00 & 12.09 & 7.18 & 14.00 \\
\hline $\mathrm{N}$ & 4055 & & & 614029 & & \\
\hline Firm age (years) & $17.07 \star \star \star$ & 16.18 & 14.00 & 13.48 & 11.45 & 11.00 \\
\hline Firm personnel & $12.34 \star \star \star$ & 95.59 & 3.20 & 8.58 & 51.25 & 2.90 \\
\hline Firm revenue $(1000 €)$ & 2840.10 & 23932.97 & 393.85 & 1873.52 & 53290.71 & 310.30 \\
\hline Firm assets $(1000 €)$ & 2932.08 & 20502.79 & 281.30 & 1739.91 & 53041.63 & 188.29 \\
\hline $\begin{array}{l}\text { Firm number of } \\
\text { plants/establishments }\end{array}$ & 1.12 & 0.59 & 1.00 & 1.18 & 3.28 & 1.00 \\
\hline $\begin{array}{l}\text { Municip. total area }(\mathrm{km} 2) \text {, } \\
2014 \text { codes }\end{array}$ & $335.91 \star \star \star$ & 488.86 & 20.75 & 1224.75 & 1464.95 & 715.48 \\
\hline Family firm $($ yes $=1$, no $=0)$ & $0.14 \star \star \star$ & & 0.00 & 0.32 & & 0.00 \\
\hline $\mathrm{N}$ & 4135 & & & 624077 & & \\
\hline
\end{tabular}

Note: $\star \star \star$ indicates the results of a t-test for differences in means which is significant at the $1 \%-$ level.

Regarding the rest of the variables, we also note some interesting differences. First, firms on the Åland Islands are considerably older on average than those in the rest of Finland (17.7 years on the Åland Islands compared to 13.48 years in the rest of Finland). They also seem to be bigger in terms of average number of employees (12.34 employees on the Åland Islands compared to 8.58 employees in the rest of Finland). These differences in averages are also statistically significant (see Table 3, column 1). For the financial measures Firm Assets and Firm Turnover, while the averages look higher on the Alland Islands than in the rest of Finland, these differences are not statistically significant. Similarly, the t-test does not lend support to the notion that firms on the Alland Islands have a lower average number of establishments (1.12 for the Åland Islands compared to 1.18 for the rest of Finland), which is 
perhaps not surprising, given the insular location. Also, firms on the Åland Islands are located in municipalities that, on average, are much smaller than those in which the firms in the rest of Finland are located $\left(335.91 \mathrm{~m}^{2}\right.$ for the Alland Islands compared to $1224.75 \mathrm{~m}^{2}$ for the rest of Finland). Interestingly, there is also a very large difference in family ownership of firms, where firms on the Åland Islands are much less likely to be family owned (14\% on the Åland Islands compared to $32 \%$ in the rest of Finland). While this is not a particular issue for this paper, it is an interesting observation worth pursuing in future research.

\section{Regression results}

Table 4 shows the result of our regression model when the dependent variable is Place Tenure for the various key firm stakeholders.

First, the Åland Island dummy is negative and statistically significant for all key firm stakeholders except for the chairman of the board. This implies that key firm stakeholders have shorter place tenure on the Aland Islands than in the rest of Finland, controlling for all of the other variables included in our model. This is in stark contrast to what we would have expected a priori, i.e., that key firm stakeholders would have a longer place tenure on the Alland Islands than in the rest of Finland.

The other variables have more or less the coefficients that one would expect. Older firms are more locally embedded, as are smaller firms. Interestingly, the larger the municipality the firm is located in, the lower our measure of local embeddedness (measured as Place Tenure) is. As discussed in Section 3, this could be due to the fact that an equal distance move for a key stakeholder is more likely to cross a municipal border if the municipality is smaller. As such, owing to the way we measure local embeddedness in this study, a move across a municipal border would show up as lower local embeddedness.

For some key stakeholders, the number of firm establishment sites has a positive relationship with local embeddedness. Also as mentioned in Section 3, this may be important to control for because of the way that we measure local embeddedness for multi-establishment firms. 
Table 4. Regression results for local embeddedness measured as place tenure for key firm stakeholders.

\begin{tabular}{lllllll}
\hline & CEO & Owner & Management & $\begin{array}{l}\text { Non- } \\
\text { management }\end{array}$ & $\begin{array}{l}\text { Board } \\
\text { chair. }\end{array}$ & $\begin{array}{l}\text { Board } \\
\text { member }\end{array}$ \\
\hline Aland Islands & $-1.193 \star \star$ & $-0.753^{\star \star}$ & $-1.155^{\star}$ & $-1.561 \star \star \star$ & -0.004 & $-0.874 \star \star$ \\
& $(0.402)$ & $(0.270)$ & $(0.482)$ & $(0.208)$ & $(0.428)$ & $(0.279)$ \\
Age & $0.064 \star \star \star$ & $0.061 \star \star \star$ & $0.062 \star \star \star$ & $0.066 \star \star \star$ & $0.050 \star \star \star$ & $0.061 \star \star \star$ \\
Firm number of & $(0.003)$ & $(0.002)$ & $(0.003)$ & $(0.002)$ & $(0.003)$ & $(0.002)$ \\
staff & -0.001 & -0.002 & $-0.001 \star$ & $0.003 \star \star \star$ & -0.001 & $-0.003 \star$ \\
Log of firm & $(0.001)$ & $(0.001)$ & $(0.000)$ & $(0.001)$ & $(0.001)$ & $(0.002)$ \\
turnover & $-0.574 \star \star \star$ & $-0.526 \star \star \star$ & $-0.559 \star \star \star$ & $-1.031 \star \star \star$ & $-0.410 \star \star \star$ & $-0.538 \star \star \star$ \\
& & & & & & \\
Log of firm assets & -0.035 & $-0.043 \star$ & $-0.295 \star \star \star$ & $-0.053 \star \star$ & $-0.154 \star \star \star$ & $-0.067 \star \star$ \\
Number of & $(0.026)$ & $(0.020)$ & $(0.039)$ & $(0.018)$ & $(0.034)$ & $(0.021)$ \\
establishment & 0.046 & $0.051 \star \star$ & 0.002 & 0.009 & 0.049 & $0.058 \star$ \\
sites & & & & & & \\
& & & & & & \\
Municipal area & $(0.024)$ & $(0.018)$ & $(0.007)$ & $(0.011)$ & $(0.028)$ & $(0.023)$ \\
size & $0.001 \star \star \star$ & $0.001 \star \star \star$ & $0.001 \star \star \star$ & $0.001 \star \star \star$ & $0.001 \star \star \star$ & $0.001 \star \star \star$ \\
& & & & & & \\
Family firm & $(0.000)$ & $(0.000)$ & $(0.000)$ & $(0.000)$ & $(0.000)$ & $(0.000)$ \\
Constant & $0.785 \star \star \star$ & -0.015 & $0.757 \star \star \star$ & $0.361 \star \star \star$ & $1.568 \star \star \star$ & $0.511 \star \star \star$ \\
& $(0.055)$ & $(0.043)$ & $(0.072)$ & $(0.035)$ & $(0.071)$ & $(0.046)$ \\
\hline R-squared & $10.938 \star \star$ & $9.880 \star \star$ & $24.858 \star \star \star$ & $25.033 \star \star \star$ & $20.358 \star \star \star$ & $11.008 \star \star$ \\
$\mathbf{N}$ & $(3.683)$ & $(3.226)$ & $(0.506)$ & $(2.228)$ & $(0.439)$ & $(3.765)$ \\
\hline & 0.064 & 0.068 & 0.108 & 0.104 & 0.068 & 0.064 \\
& 431058 & 608782 & 177436 & 600412 & 268396 & 603447 \\
\hline
\end{tabular}

Notes: Regressions are ordinary least squares regressions with standard errors clustered the firm level. Numbers in brackets are standard errors. All regressions also include 9 year dummies and 96 industry dummies. ' $\star$ ', ' $\star \star$ ', and ' $\star \star \star$ ' denote statistical significance at the $10 \%, 5 \%$, and $1 \%$ levels, respectively. With the exception of fixed industry dummies, none of the explanatory variables had a variance inflation factor higher than 3.5. Correlations between the explanatory variables were generally quite low, with a maximum of 0.54 between the log of firm turnover and the $\log$ of firm assets.

Finally, it is apparent that family firms are more locally embedded than non-family firms, a finding which is consistent with earlier literature (e.g., Bird \& Wennberg, 2014). In Table 5, the results of the regressions where distance is used as a dependent variable is presented. In these regressions, a negative sign indicates more local embeddedness, i.e., the geographical distance of the key firm stakeholders to the focal firm is longer (higher distance corresponds to lower local embeddedness). Here, the Åland Islands dummy mostly has the anticipated negative relationship, indicating that firms located on the Åland Islands are more locally embedded than those in the rest of Finland. The other dependent variables have similar relationships with the dependent variable, as shown in Table 4 . Because of the construction 
of the dependent variable, the coefficients in Table 5 are of opposite sign compared to what they were in Table 4.

Table 5. Regression results for local embeddedness measured as distance for key firm stakeholders.

\begin{tabular}{|c|c|c|c|c|c|c|}
\hline & CEO & Owner & Management & $\begin{array}{l}\text { Non- } \\
\text { management }\end{array}$ & $\begin{array}{l}\text { Board } \\
\text { chair. }\end{array}$ & $\begin{array}{l}\text { Board } \\
\text { member }\end{array}$ \\
\hline \multirow[t]{2}{*}{ Åland Islands } & -2.957 & $-7.974 \star \star \star$ & -4.528 & $-4.104 \star \star$ & $-9.956^{\star \star}$ & $-9.199 \star \star \star$ \\
\hline & $(2.402)$ & $(1.782)$ & $(2.750)$ & $(1.562)$ & (3.034) & $(1.521)$ \\
\hline \multirow[t]{2}{*}{ Age } & $-0.515^{\star \star \star}$ & $-0.502^{\star \star \star}$ & $-0.534 \star \star \star$ & $-0.486^{\star \star \star}$ & $-0.566^{\star \star \star}$ & $-0.499 \star \star \star$ \\
\hline & $(0.018)$ & $(0.018)$ & $(0.021)$ & $(0.012)$ & $(0.027)$ & $(0.018)$ \\
\hline \multirow{2}{*}{$\begin{array}{l}\text { Firm number of } \\
\text { staff }\end{array}$} & 0.011 & $0.018^{\star}$ & $0.013 \star \star$ & -0.002 & 0.005 & $0.025^{\star}$ \\
\hline & $(0.006)$ & $(0.009)$ & $(0.004)$ & $(0.003)$ & $(0.006)$ & $(0.010)$ \\
\hline \multirow{2}{*}{$\begin{array}{l}\text { Log of firm } \\
\text { turnover }\end{array}$} & $0.605 \star \star$ & $0.916 \star \star \star$ & $0.807^{\star}$ & $3.035 \star \star \star$ & $0.741^{\star}$ & $0.828 \star \star \star$ \\
\hline & $(0.224)$ & $(0.211)$ & $(0.358)$ & $(0.176)$ & $(0.360)$ & $(0.214)$ \\
\hline \multirow{2}{*}{$\begin{array}{l}\text { Log of firm } \\
\text { assets }\end{array}$} & $1.177 \star \star \star$ & $1.685^{\star \star \star}$ & $3.392 \star \star \star$ & $1.409 \star \star \star$ & $2.752 \star \star \star$ & $1.696 \star \star \star$ \\
\hline & $(0.218)$ & $(0.193)$ & $(0.331)$ & $(0.166)$ & $(0.358)$ & $(0.198)$ \\
\hline \multirow{2}{*}{$\begin{array}{l}\text { Number of } \\
\text { establishment } \\
\text { sites }\end{array}$} & $-0.280^{\star}$ & $-0.358^{\star}$ & 0.041 & $-0.059^{\star}$ & $-0.416^{\star}$ & $-0.402^{\star \star}$ \\
\hline & $(0.123)$ & $(0.144)$ & $(0.103)$ & $(0.024)$ & $(0.200)$ & $(0.155)$ \\
\hline \multirow{2}{*}{$\begin{array}{l}\text { Municipal area } \\
\text { size }\end{array}$} & $0.004 \star \star \star$ & $0.005 \star \star \star$ & $0.003 \star \star \star$ & $0.004 \star \star \star$ & $0.007 \star \star \star$ & $0.005 \star \star \star$ \\
\hline & $(0.000)$ & $(0.000)$ & $(0.000)$ & $(0.000)$ & $(0.001)$ & $(0.000)$ \\
\hline \multirow[t]{2}{*}{ Family firm } & $-2.693 \star \star \star$ & -0.281 & $-2.767 \star \star \star$ & $-2.276^{\star \star \star}$ & $-8.205^{\star \star \star}$ & $-1.757 \star \star \star$ \\
\hline & $(0.416)$ & $(0.375)$ & $(0.513)$ & $(0.305)$ & $(0.631)$ & $(0.386)$ \\
\hline \multirow[t]{2}{*}{ Constant } & 104.720 & 101.292 & $-38.369 \star \star \star$ & $-42.799 \star \star \star$ & $-25.640 \star \star \star$ & 95.299 \\
\hline & $(89.479)$ & (85.055) & (3.939) & $(6.516)$ & (3.869) & $(90.129)$ \\
\hline R-squared & 0.038 & 0.047 & 0.057 & 0.052 & 0.051 & 0.042 \\
\hline $\mathbf{N}$ & 431058 & 608782 & 177436 & 600412 & 268396 & 603447 \\
\hline
\end{tabular}

Notes: See notes to Table 4.

\section{Discussion and conclusion}

In this paper, we hypothesized that, because of legal and geographical factors which act as barriers to entry, we would see higher levels of firm local embeddedness on the Åland Islands compared to the rest of Finland. The results of the study support this hypothesis when we measure local embeddedness as distance, but not when we measure local embeddedness as place tenure.

Why do we get this somewhat counterintuitive result regarding our place tenure measure? One explanation may be that the "barriers to entry" described in the paper are not overly important for migration and recruitment of key stakeholders in a firm, and that other forces, some of which we may not be aware of, are more important for local embeddedness. 
Also, perhaps only a little embeddedness is required in a very small place. Familiarity is already high in a more remote place like the Åland Islands, and it may be more important to acquire knowledge and expertise amongst key stakeholders from places outside of the region. It can be hypothesized that perhaps there is a dark side to local embeddedness, whereby too much local embeddedness is harmful for firm performance - and this negative effect is somehow context dependent, such that the effect is different depending on the size or relative peripherality of the location (Taylor, 2005). Another interesting issue concerns exports. Obviously, the smaller a region is, the larger the share of its GDP that is exported, i.e., there is generally a negative relationship between the size of an economy and the openness of the economy. Consequently, one could hypothesize that for a firm to be successful in exports, local embeddedness measured in the way it is done in this paper may not necessarily be what firms most need. For the case of the Åland Islands, goods which are shipped to the Finnish mainland are probably conceptually thought of as exports, even though they do not cross a country border. However, we cannot construct an export measure of sales from the Åland Islands to the Finnish mainland with the data at hand, so this hypothesis remains untested. Nevertheless, it is an interesting avenue for further research to investigate to what extent local embeddedness will help firms in starting to export or increasing their exports. Perhaps that is an area where the concept of the "dark" side of local embeddedness is relevant; being too locally embedded is not necessarily conducive to export success. In that case, a resource-based theory of entrepreneurship (Wernerfelt, 1984) would be better suited for future studies, which would also be consistent with the results in this paper.

Overall, it is likely that the supply of key stakeholders is different for islands than for other locations. Therefore, the mobility of these stakeholders to and from islands is also an important issue for future research. Furthermore, autonomous regions within larger countries could also be interesting cases for further studies of local embeddedness.

\section{Acknowledgments}

Our dear friend, colleague, and co-author Jouko Kinnunen sadly passed away during the referee process for this paper. We dedicate this paper to his memory. His research efforts for the common good and for the benefit of the Alland Islands will always be remembered.

All three authors have contributed equally. The study has been partly funded by the Ålands självstyrelses 75-års jubileumsfond. The data cannot be provided due to limited public access.

\section{References}

Aalto-Setälä, V., Kinnunen, J., \& Koistinen, K. (2004). Reasons for high food prices in small market areas: The case of the Åland Islands. Agribusiness: An International Journal, 20(1), 17-29.

Bassanini, A., Nunziata, L., \& Venn, D. (2014). Job protection legislation and productivity growth in OECD countries. Economic Policy, 24(58), 349-402. https://doi.org/10.1111/j.1468-0327.2009.00221.x

Baù, M., Chirico, F., Pittino, D., Backman, M., \& Klaesson, J. (2019). Roots to grow: Family firms and local embeddedness in rural and urban contexts. Entrepreneurship Theory and Practice, 43(2), 360-385. https://doi.org/10.1177/1042258718796089 
Bird, M., \& Wennberg, K. (2014). Regional influences on the prevalence of family versus non-family start-ups. Journal of Business Venturing, 29(3), 421-436. https://doi.org/10.1016/j.jbusvent.2013.06.004

Böckerman, P., \& Maliranta, M. (2001). Regional disparities in gross job and worker flows in Finland. Finnish Economic Papers, 14(2), 84-103.

Dahl, M. S., \& Sorenson, O. (2012). Home sweet home: Entrepreneurs' location choices and the performance of their ventures. Management Science, 58(6), 1059-1071. https://doi.org/10.1287/mnsc.1110.1476

Dubois, A. (2016). Transnationalising entrepreneurship in a peripheral region: The translocal embeddedness paradigm. Journal of Rural Studies, 46, 1-11.

Eurostat. (n.d.). Eurostat: My region. Retrieved August 22, 2019, from https://ec.europa.eu/eurostat/cache/RCI/myregion/

Eurostat. (2008). NACE Rev. 2: Statistical classification of economic activities in the European Community [Eurostat Methodologies and Working Papers]. European Commission. https://ec.europa.eu/eurostat/web/products-manuals-and-guidelines/-/ks-ra-07-015

Granovetter, M. (2005). The impact of social structure on economic outcomes. Journal of Economic Perspectives, 19(1), 33-50.

Granovetter, M. (1985). Economic action and social structure: The problem of embeddedness. The American Journal of Sociology, 91(3), 481-510.

Granovetter, M. (1973). The strength of weak ties. American Journal of Sociology, 78(6), 1360-1380.

Greenberg, Z., Farja, Y., \& Gimmon, E. (2018). Embeddness and growth of small businesses in rural regions. Journal of Rural Studies, 62, 174-182.

Herolf, G., Åkermark, S. S., Ackrén, M., Lyck, L., Malloy, T. H., Palmer, R., Rógvi, K. á, Stephan, S., \& Suksi, M. (2015). Självstyrelser $i$ Norden $i$ ett fredsperspektiv: Färöarna, Grönland och Åland. Nordisk Ministerråd. https://doi.org/10.6027/ANP2015-731

Hess, M. (2004). 'Spatial' relationships? Towards a reconceptualization of embeddedness. Progress in Human Geography, 28(2), 165-186. https://doi.org/10.1191/0309132504ph479oa

Kinnunen, J. (2005). Migration, imperfect competition and structural adjustment: Essays on the economy of the Aland Islands. Helsinki School of Economics.

Korsgaard, S., Müller, S., \& Tanvig, H. W. (2015). Rural entrepreneurship or entrepreneurship in the rural - Between place and space. International Journal of Entrepreneurial Behavior E Research, 21(1), 5-26. https://doi.org/10.1108/IJEBR-11-2013-0205

Maliranta, M., \& Nurmi, S. (2019). Business owners, employees, and firm performance. Small Business Economics, 52(1), 111-129. http://doi.org/10.1007/s11187-018-0029-1

Maliranta, M., Mohnen, P., \& Rouvinen, P. (2009). Is inter-firm labor mobility a channel of knowledge spillovers? Evidence from a linked employer-employee panel. Industrial and Corporate Change, 18(6), 1161-1191. https://doi.org/10.1093/icc/dtp031

Ministry for Foreign Affairs of Finland. (n.d.). The special status of the Aland Islands. Retrieved August 23, 2019, from https://um.fi/the-special-status-of-the-aland-islands

Müller, S., \& Korsgaard, S. (2018). Resources and bridging: The role of spatial context in rural entrepreneurship. Entrepreneurship \& Regional Development, 30(1-2), 224-255.

Polanyi, K. (1944). The great transformation. Farrar \& Rinehart. 
Statistics Finland. (n.d.). The data. Products and services: Micro data. https://www.stat.fi/tup/mikroaineistot/aineistot en.html

Tax Administration. (n.d.). Aland Islands tax border and importing goods. Verohallinto. https://www.vero.fi/en/businesses-and-corporations/taxes-andcharges/vat/international-commerce/value-added-taxation-of-importedgoods $/ \%$ C3\%A5land-islands-tax-border-and-importing-goods/

Taylor, M. (2005). Embedded local growth: A theory taken too far? In R. A. Boschma \& R. C. Kloosterman (Eds.), Learning from clusters (pp. 69-88). Springer.

Uzzi, B. (1999). Embeddedness in the making of financial capital: How social relations and networks benefit firms seeking financing. American Sociological Review, 64(4), 481-505. https://doi.org/10.2307/2657252

Wernerfelt, B. (1984). A resource-based view of the firm. Strategic Management Journal, 5(2), 171-180. https://doi.org/10.1002/smj.4250050207

Williams, R. C. (2007). Excluding to protect: Land rights and minority protection in international law. In S. S. Åkermark (Ed.), Den åländska hembygdsrätten (pp. 91-121). Ålands lagting \& Ålands fredsinstitut. 